Etihad: Journal of Islamic Banking and Finance

Vol. 1, No. 2 Juli-Desember: 132-145

\title{
IMPLEMENTASI RESTRUKTURISASI PEMBIAYAAN MURABAHAH PADA MASA PANDEMI COVID-19 DI BANK BJB SYARIAH KCP BOGOR
}

\author{
Riesha Mawarni Baity $^{1^{*},}$ Trisiladi Supriyanto $^{2}$, Siwi Nugraheni ${ }^{3}$ \\ 1,2,3 Universitas Pembangunan Nasional Veteran Jakarta, Indonesia \\ Email : riesha.mawarni@upnvj.ac.id, trisiladi.supriyanto@gmail.com, \\ siwinugraheni@upnvj.ac.id
}

\begin{abstract}
The purpose of this study was to determine the implementation of murabaha financing restructuring at Bank BJB Syariah Bogor Branch and the implementation of financing restructuring based on POJK Number 48/POJK.03/2020 and DSN MUI Fatwa Number 47,47,49/DSN -MUI/II/2005 at Bank BJB Syariah Bogor Branch. This study uses qualitative research with a case study approach using data collection techniques through observation, interviews with three informants, and documentation of related parties from the Bank BJB Syariah Bogor branch. The results showed that the practice of restructuring murabaha financing at Bank BJB Syariah KCP Bogor was carried out as an effort to save non-performing financing. The implementation of restructuring when viewed from POJK, especially POJK 48 shows several important points that must be considered by banks. Bank BJB Syariah KCP Bogor, has guidelines for determining debtors affected by COVID-19. In addition, the implementation of the restructuring takes into account the DSN MUI Fatwa No. 47,48,49, regarding the settlement of problematic murabaha financing, the absence of additional costs, and the conversion of the contract.
\end{abstract}

Keywords: COVID-19, Murabahah ,Financing, Restructuring.

Abstrak: Tujuan penelitian ini adalah untuk mengetahui implementasi restrukturisasi pembiayaan murabahah pada Bank BJB Syariah cabang Bogor dan implementasi restrukturisasi pembiayaan berdasarkan POJK Nomor 48/POJK.03/2020 dan Fatwa DSN MUI No. 47,47,49/DSN-MUI/II/2005 di Bank BJB Syariah cabang Bogor. Penelitian ini menggunakan jenis penelitian kualitatif dengan pendekatan studi kasus menggunakan teknik pengumpulan data melalui observasi, wawancara dengan tiga informan dan dokumentasi terhadap pihak yang terkait dari Bank BJB Syariah cabang Bogor. Hasil dari penelitian menunjukkan bahwa praktek restrukturisasi pembiayaan murabahah di Bank BJB Syariah KCP Bogor dijalankan sebagai upaya penyelamatan pembiayaan yang bermasalah. Pelaksanaan restrukturisasi jika ditinjau dari POJK, khususnya POJK 48 menunjukkan beberapa poin penting yang harus diperhatikan oleh perbankan. Bank BJB Syariah KCP Bogor, memiliki pedoman untuk menetapkan debitur yang terdampak COVID-19. Selain itu pelaksanaan restrukturisasi memperhatikan Fatwa DSN MUI No 47,48,49, mengenai penyelesaian pembiayaan murabahah bermasalah, tidak adanya tambahan biaya dan konversi akad.

Kata Kunci: COVID-19, Murabahah, Pembiayaan, Restrukturisasi. 
Etihad: Journal of Islamic Banking and Finance

Vol. 1, No. 2 Juli-Desember: 132-145

\section{PENDAHULUAN}

Perbankan dapat dijadikan sebagai sarana strategis untuk mengupayakan pembangunan ekonomi Indonesia. Hal ini dikarenakan fungsi bank adalah sebagai perantara (intermediary) yakni yang menghimpun serta menyalurkan dana. Bank akan melakukan penghimpunan dana yang ada di masyarakat dalam bentuk tabungan, deposito, dan produk lainnya. Kemudian perbankan akan memberikan dana yang sudah dikumpulkan dengan wujud pembiayan. Perbankan juga dijadikan sebagai alat pemerintah untuk pembangunan ekonomi negara lewat pembiayaan seluruh jenis usaha pembangunan yang berkontribusi pada penghasilan negara. Di Indonesia perbankan dibagi oleh dua sistem yakni konvensional serta syariah. Sistem ini ada sejak terbitnya UU No.10 Tahun 1998 amandemen UU No.7 Tahun 1992 perihal perbankan. Sistem ini sebagai tombak awalnya muncul bank syariah di Indonesia (Soetopo et al., 2016).

\begin{tabular}{cccc}
\hline No & Tahun & $\begin{array}{c}\text { PYD } \\
\text { (Pembiayaan Yang } \\
\text { Disalurkan) }\end{array}$ & Pembiayaan Murabahah \\
\hline 1. & 2017 & $293,5 \mathrm{~T}$ & $53,23 \%$ \\
2. & 2018 & $329,3 \mathrm{~T}$ & $49,12 \%$ \\
3. & 2019 & $365,1 \mathrm{~T}$ & $49,95 \%$ \\
4. & 2020 & $394,6 \mathrm{~T}$ & $46,11 \%$ \\
\hline
\end{tabular}

Tabel.1 Penyaluran pembiayaan keseluruhan dan pembiayaan murababah Sumber: Snapshot Perbankan Syariah OJK (data diolah)

Akad yang menjadi dominasi perbankan syariah adalah akad murabahah, sebab pembiayaan murabahah beresiko lebih sedikit serta lebih aman untuk shareholder (Soeikromo, 2017). Tabel 1 menunjukkan bahwa saat ini akad murabahah mendominasi pembiayaan di perbankan syariah dari data OJK, dari total pembiayaan yang disalurkan, pembiayaan terbesar tercatat memakai akad murabahah, meski setiap tahunnya menunjukkan angka yang menurun. Terdapat beberapa faktor yang menyebabkan angka tersebut menurun, salah satunya adanya pandemi Covid-19 (OJK, 2020c).

\begin{tabular}{rccc}
\hline No. & Tahun & NPF Gross & NPF Net \\
\hline 1. & 2017 & $3,87 \%$ & $2,13 \%$ \\
2. & 2018 & $2,85 \%$ & $1,74 \%$ \\
3. & 2019 & $3,26 \%$ & $2,02 \%$ \\
4. & 2020 & $3,24 \%$ & $1,84 \%$ \\
\hline
\end{tabular}

Tabel.2 Tingkat NPF Gross dan NPF Net

Sumber: Snapshot Perbankan Syariah OJK (data diolah)

Tabel 2 menunjukkan nilai Non Performing Financing Gross dan juga Non Performing Financing Net yang diperoleh dari tahun 2017 hingga tahun 2020. NPF Gross 
Etihad: Journal of Islamic Banking and Finance

Vol. 1, No. 2 Juli-Desember: 132-145

menggambarkan perbandingan total pembiayaan tingkat kolektabilitas 3-5 serta total pembiayaan oleh Bank, sehingga perlu adanya perhatian khusus. NPF Net yakni pembiayaan yang termasuk bagian kurang lancar, diragukan, serta macet. Tingkat NPF yang besar di bank syariah berarti mutu pembiayaan bank tidak sehat. NPF ditimbulkan dari adanya pembiayaan bermasalah yang terjadi.

Terdapat beberapa faktor yang membuat suatu pembiayaan menjadi bermasalah. Adanya faktor internal dari bank seperti kesalahan manajemen bank. Faktor selanjutnya dari kondisi nasabah, seperti akibat dari ketidakmampuan nasabah dalam membayar karena kondisi ekonomi maupun terjadi kesengajaan atau watak nasabah (moral hazard). Penyebab faktor eksternal dapat timbul, seperti wabah penyakit yang kini sedang melanda seluruh dunia. Dampak dari COVID-19 memberikan imbas yang besar terhadap kemampuan nasabah dalam membayarkan kewajibannya.

Upaya yang dilakukan pemerintah dalam menanggulangi krisis keuangan saat pandemi adalah menerbitkan peraturan demi keberlangsungan keuangan negara. Ketentuan tersebut adalah POJK Nomor 48/POJK.03/2020 perihal perubahan atas POJK Nomor 11/POJK.03.2020 perihal stimulus perekonomian nasional menjadi regulasi countercyclical pengaruh Covid-19. Peraturan ini diterbitkan dalam rangka upaya menjaga stabilitas sistem keuangan, optimalisasi kerja perbankan serta mendukukung pertumbuhan ekonomi dengan hati-hati serta menjauhi adanya moral hazard.

Selain POJK Nomor 48/POJK.03/2020, Fatwa- Fatwa DSN MUI juga menjadi acuan yang dapat dijadikan sebagai indikator pelaksanaan kegiatan restrukturisasi pembiayaan murabahah. Pada Fatwa DSN MUI yang menjadi acuan menjabarkan mengenai penyelesaian piutang murabahah untuk nasabah yang tidak dapat melakukan pembayaran, menjadwalkan kembali tagihan murabahah serta perihal konversi akad murabahah.

Penelitian (Wahyudi \& Arbay, 2011) yang berjudul The Impact of OJK Regulation No. 48/POJK.03/2020 on the Quality of Credit and Risk Management of Banking Credit menunjukkan hasil bahwa adanya regulasi ini dapat menjadi stabilitas perbankan kinerja dengan menjaga angka NPL dibawah 5\% dan menjadi referensi bagi bank dalam manajemen risiko dengan model yang relevan dengan kondisi ekonomi saat pandemi COVID-19. Selanjutnya, Penelitian (Albanjari \& Kurniawan, 2020) yang berjudul Implementasi Kebijakan Peraturan Otoritas Jasa Keuangan (POJK) No.11/POJK.03/2020 dalam menekan Non Performing Financing (NPF) pada Perbankan Syariah, memiliki hasil bahwa bank menerapkan kebijakan yang dapat memberi solusi kepada nasabah pembiayaan syariah yang pembiayaannya bermasalah, nasabah dapat mengajukan restrukturisasi kepada bank. Nasabah tersebut baik terkena dampak secara langsung maupun tidak dari COVID-19.

Didasarkan penelitian beberapa pihak, belum ada penelitian yang fokus terhadap mekanisme implementasi restrukturisasi murabahah secara menyeluruh terlebih pada masa pandemi COVID-19. Selain itu penulis ingin mengidentifikasi implementasi Bank BJB Syariah perihal restrukturisasi pembiayaan berdasarkan POJK Nomor 48/POJK.03/2020 perihal stimulus perekonomian nasional menjadi regulasi countercyclical pengaruh COVID-19 
Etihad: Journal of Islamic Banking and Finance

Vol. 1, No. 2 Juli-Desember: 132-145

sebagai pengganti POJK No.11/POJK.03/2020 dan Fatwa DSN MUI yang relevan dengan implementasi restrukturisasi pembiayaan murabahah.

Dari pemaparan di atas, maka dapat dirumuskan masalah bahwa: Bagaimana praktik restrukturisasi pembiayaan murabahah pada Bank BJB Syariah cabang Bogor? dan Bagaimana implementasi Bank BJB Syariah cabang Bogor terhadap restrukturisasi pembiayaan murabahah berdasarkan Peraturan Otoritas Jasa Keuangan (POJK) No. 48/POJK.03/2020 dan Fatwa DSN MUI? Adapun tujuan penelitian yang hendak dicapai adalah mengetahui implementasi restrukturisasi pembiayaan murabahah pada Bank BJB Syariah cabang Bogor dan mengetahui implementasi restrukturisasi pembiayaan murabahah di Bank BJB Syariah cabang Bogor berdasarkan Peraturan Otoritas Jasa Keuangan (POJK) No. 48/POJK.03/2020 dan Fatwa DSN MUI.

\section{TINJAUAN LITERATUR}

\section{Pembiayaan Murabahah}

Dari sudut pandang fikih, murabahah merupakan peralihan dari pinjaman tradisional ke perjanjian jual beli, yang mana pembeli dan penjual sepakat dalam harga jual serta lama pembayaran. Perdagangan adalah jaiz (diperbolehkan) dalam hukum Islam. Pada saat penandatanganan akad jual beli, harga jual akan dimasukkan dalam murabahah. Harga yang disepakati tidak dapat diubah selama masa kontrak. Jika ada perubahan, kontrak akan dibatalkan. Metode pembayaran dan batas waktu akan disepakati oleh para pihak dalam kontrak. Bisa dicicil atau tidak (Hasbi \& Hadi, 2016). Dalam kamus istilah keuangan dan Perbankan Syariah yang diterbitkan oleh Direktorat Perbankan Syariah, Bank Indonesia menyatakan bahwasanya murabahah yakni jual beli barang yang disepakati. Penjual menginformasikan harga pokok serta laba yang diambil (Wiroso, 2007, hlm. 169). Landasan Hukum Pembiayaan Murabahah:

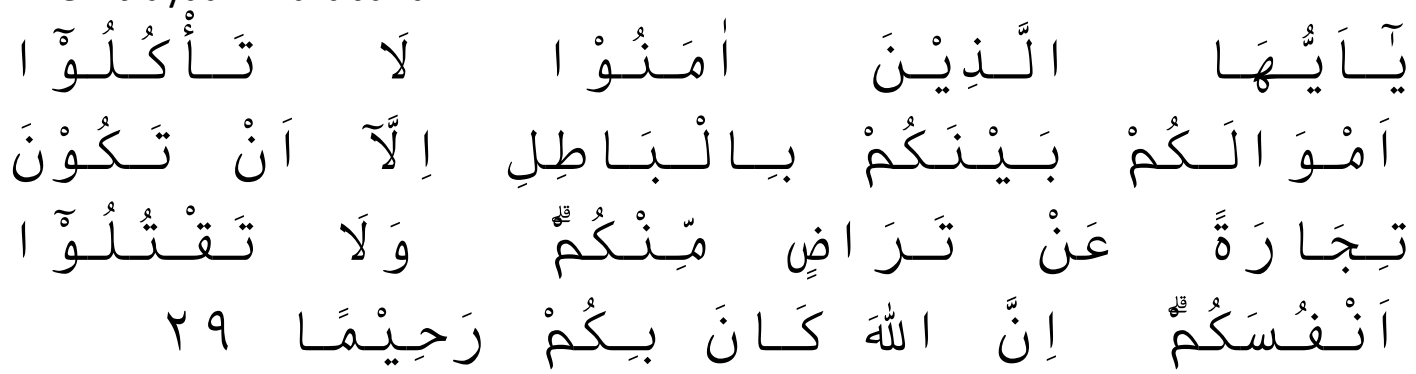

Wahai orang-orang yang beriman, janganlah kamu memakan harta sesamamu dengan cara yang batil (tidak benar), kecuali berupa perniagaan atas dasar suka sama suka di antara kamu. Janganlah kamu membunuh dirimu. Sesungguhnya Allah adalah Maha Penyayang kepadamu (QS An-Nisa': 29).

\section{Rukun dan Syarat Murabahah}

Syarat syarat yang harus dipenuhi adalah sebagai berikut (Rozalinda, 2017):

1. Pembeli kedua harus mengetahui harga pokok.

2. Selain harga pokok, laba juga harus diketahui.

3. Modal merupakan benda yang ada perbandingannya di pasaran seperti benda yang 
Etihad: Journal of Islamic Banking and Finance

Vol. 1, No. 2 Juli-Desember: 132-145

ditakar, ditimbang, dan benda yang dihitung atau sesuatu yang nilainya diketahui.

4. Murabahah tidak boleh dilakukan terhadap harta riba dan memunculkan riba karena dinisbahkan pada harga pokok.

5. Akad jual beli yang pertama dilakukan adalah sah jika akad jual beli pertama fasid maka murabahah tidak boleh dilakukan.

\section{Pembiayaan Bermasalah}

Pembiayaan bermasalah yakni keadaan, di mana pemberian modal oleh bank syariah kepada nasabah terjadinya pembiayaan yang tidak lancar, gagal bayar, dan bahkan pembiayaan tersebut macet. Pada situasi ini debitur tidak memenuhi syarat perjanjian serta tidak menepati janji atau wanprestasi. Pembiayaan yang bermasalah akan menimbulkan NPF yang berpengaruh terhadap kinerja bank syariah (Djami, 2012).

Kategori pembiayaan bermasalah dikelompokkan menjadi 3 (Ismail, 2013) :

1. Kurang Lancar, hal ini terjadi bila pelunasan cicilan pokok dan margin melebihi 90 hari hingga 180 hari.

2. Diragukan, ialah jika terjadi tunggakan pembayaran angsuran pokok dan margin melewati 180 hari hingga 270 hari.

3. Macet, ialah apabila tunggakan pembayaran angsuran pokok dan margin yang telah melewati 270 atau lebih, maka bank akan mengalami kerugian yang disebabkan oleh pembiayaan macet.

\section{Penyebab Pembiayaan Bermasalah}

Ada dua aspek penyebab terjadinya pembiayaan bermasalah di bank syariah (Umam, 2016) :

1. Aspek Internal

Faktor yang ada didalam lembaga keuangan itu sendiri, seperti faktor manajerial, seperti:

a. Kebijakan piutang yang kurang tepat.

b. Lemahnya kebijakan pembelian dan penjualan

c. Pemakaian anggran tidak sesuai rencana

d. Modal tidak mencukupi

2. Aspek Eksternal

Faktor eksternal merupakan faktor yang berada diluar kekuasaan manajemen perusahaan, seperti:

a. Watak nasabah yang tidak dapat dipercaya saat memberikan data serta laporan kegiatannya.

b. Keterampilan mengolah nasabah tidak baik sampai kalah dalam persaingan

c. Terjadinya perselisihan dalam internal perusahaan

d. Terjadinya bencana alam

e. Regulasi yang dibuat oleh pemerintah yang membengaruhi sektor perekonomian

f. Menurun nya perekonomian secara global. 
Etihad: Journal of Islamic Banking and Finance

Vol. 1, No. 2 Juli-Desember: 132-145

\section{Restrukturisasi}

Dalam PBI No. 13/9/PBI/2011 restrukturisasi pembiayaan merupakan usaha bank untuk menolong nasabah memenuhi kewajiban melalui penataan ulang, penyesuaian dan penyesuaian kembali. Bank dapat memberikan restrukturisasi pembiayaan bagi nasabah yang masih mempunyai prospek usaha untuk menyelesaikan utangnya. Dalam upaya mengurangi risiko kerugian, lembaga keuangan syariah wajib menjaga mutu pembiayaan. Pengaturan pembiayaan reorganisasi bank syariah serta UUS diatur pada PBI Nomor. 10/18/PBI/2008 Reorganisasi perbankan syariah dan pembiayaan UUS berubah menjadi Bank Indonesia No. 13/9/PBI/2011(Hariyanto et al., 2018).

Penanganan pembiayaan bermaasalah didasarkan PBI No. 13/9/PBI/2011 perihal restrukturisasi (Bank Indonesia, 2011). Restrukturisasi yakni salah satu usaha untuk menjadi solusi bagi nasabah yang kesulitan dalam menangani kewajiban. Restrukturisasi dijalankan lewat:

1. Penjadwalan kembali (rescheduling), yakni berubahnya jadwal pembayaran kewajiban nasabah atau lama waktunya;

2. Persyaratan kembali (reconditioning), yakni berubahnya persyaratan pembiayaan baik sebagian atau seluruh dengan tidak menambahkan pokok kewajiban nasabah yang wajib diberikan pada bank, terdiri dari peubahan jadwal pembayaran, jumlah angsuran, jangka waktu, serta pemberian potongan.

3. Penataan kembali (restructuring), adalah berubahnya syarat pembiayaan termasuk tambahan anggaran fasilitas pembiayaan bank, konversi akad pembiayaan, konversi pembiayaan sebagai surat berharga syariah berjangka waktu menengah, serta perubahan proyeksi

Landasan Hukum :

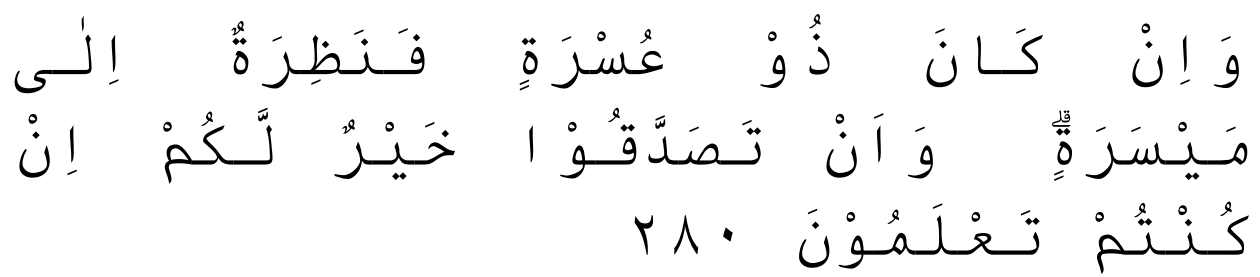

Jika dia (orang yang berutang itu) dalam kesulitan, berilah tenggang waktu sampai dia memperoleh kelapangan. Kamu bersedekah (membebaskan utang) itu lebih baik bagimu apabila kamu mengetahui(-nya). (QS Al-Baqarah: 280)

\section{Peraturan Otoritas Jasa Keuangan Nomor: 48/POJK.03/2020}

Restrukturisasi kredit atau pembiayaan dapat dilakukan terhadap seluruh kredit atau pembiayaan yang diberikan kepada debitur yang terkena dampak penyebaran coronavirus disease 2019 (COVID-19) termasuk debitur usaha mikro, kecil, dan menengah tanpa batasan plafon. Bank dalam penerapan regulasi restrukturisasi harus tetap meninjau jalannya manajemen risiko sesuai pada regulasi OJK perihal implementasi manajemen risiko Bank. Manajemen risiko antara lain:

1. Bank mempunyai acuan dalam penetapan debitur yang terdampak COVID-19 yang 
Etihad: Journal of Islamic Banking and Finance

Vol. 1, No. 2 Juli-Desember: 132-145

terendah berisi:

a. Kriteria debitur yang ditetapkan terdampak COVID-19

b. Bagian yang terdampak COVID-19;

2. Memberlakukan evaluasi kepada debitur yang masih bertahan dari COVID-19 serta mempunyai prospek usaha menyebabkan mampu direstrukturisasi pembiayaan sesuai dengan POJK;

3. Menyiapkan cadangan bag debitur yang tidak dapat sanggup sesuda restrukturisasi kredit sesuai dengan POJK;

4. Mempertimbangkan ketahanan modal serta tambahan pembuatan cadangan untuk antisipasi menurunnya mutu pembiayaan yang mengalami restrukturisasi, bank akan membagi dividen atau tantiem;

5. Melakukan uji ketahanan tiap periode untuk menurunnya mutu pembiayaan yang mengalami restrukturisasi serta dampaknya pada likuiditas serta permodalan Bank.

\section{Strategi Penanganan Pembiayaan Bermasalah di Masa Pandemi}

Stategi yang dapat dilakukan oleh Account Officer Bank antara lain adalah sebagai berikut (Maulana \& Hendri, 2016) :

1. Konsultasi

Pada umumnya di keadaan normal, Bank akan memanggil pihak yang bersangkutan untuk datang ke Bank untuk menanyakan alasan keterlambatan nasabah serta segala hal yang terkait usaha nasabah. Dalam keadaan seperti ini, maka harus digunakan cara lain yaitu melalui online, dengan catatan penanganan pembiayaan bermasalah tetap dinegoisasikan agar nasabah tetap dapat melakukan pelunasan pembiayaan serta bank tidak merugi. Bank dapat melayangkan teguran menggunakan Surat Peringatan (SP). Pemberian SP paking banyak 3x dengan jarak 7 hari.

a. Negosiasi

Bank akan menawarkan restrukturisasi pembiyaan bagi nasabah. Syarat utamanya adalah nasabah mengalami penurunan pendapatan namun prospek usaha nya baik dan masih memiliki kemampuan dalam melunasi kewajibannya setelah restrukturisasi.

b. Penjualan atau eksekusi jaminan

Apabila hasil penilaian ulang pembiayaan menyatakan usaha nasabah tidak berprospek atau tidak responsive melakukan pelunasan kewajiban, maka bank akan menjual jaminan. Nasabah menjual jaminannya sendiri, dengan mencari pembeli, tanpa bantuan bank. Hasil penjualannya untuk melunasi kewajibannya, jika ada sisa kelebihan penjualan tersebut uang tersebut akan menjadi miliki nasabah.

c. Penyelesaian melalui badan peradilan

Jika seluruh cara cara di atas tidak berhasil, maka Bank serta nasabah akan mengatasi pembiayaan bermasalah lewat lembaga peradilan.

\section{Fatwa DSN No. 47/DSN-MUI/II/2005}

LKS diperbolehkan menyelesaikan murabahah untuk nasabah yang tidak mampu 
Etihad: Journal of Islamic Banking and Finance

Vol. 1, No. 2 Juli-Desember: 132-145

melakukan pelunasan pendanaan sesuai total serta waktu yang disepakati, dengan syarat antara lain:

1. Objek murabahah atau jaminan lain dijual nasabah lewat LKS dengan harga yang disepakati;

2. Sisa hutang akan dilunasi oleh nasabah dari hasil penjualan;

3. Jika lebih dari hasil penjualan setelah kewajibannya lunas, maka sisanya dapat dikembalikan kepada nasbaah;

4. Jika hasil penjualan < sisa hutang, maka nasabah berkewajiban untuk melunasi sisa hutang tersebut;

5. Jika nasabah tidak dapat melakukan pembayaran sisa utangnya, maka dibebaskan LKS;

\section{Fatwa DSN No. 48/DSN-MUI/II/2005}

LKS mampu menjadwalkan kembali tagihan murabahah untuk nasabah yang tidak dapat melakukan pelunasan pembiayaan sesuai jumlah serta waktu yang telah disetujui, dengan syarat (DSN MUI, 2005):

1. Sisa tagihan tidak bertambah;

2. Pembebanan biaya pada rescheduling yaitu biaya riil;

3. Perpanjangan masa pembayaran didasarkan persetujuan kedua belah pihak.

\section{Fatwa DSN No. 49/DSN-MUI/II/2005}

LKS diperbolehkan menciptakan akad baru untuk nasabah yang tidak mampu melunasi kewajiban murabahah nya sesuai waktu serta jumlah yang disetujui, namun masih prospektif, dengan syarat:

1. Akad murabahah dihentikan dengan cara:

a. Objek murabahah dijual kepada LKS oleh nasabah dengan harga pasar;

b. Nasabah melakukan pelunasan sisa kewajibannya pada LKS dari hasil penjualan;

c. Jika hasil dari penjualan objek lebih dari sisa hutang yang harus dibayarkan kepada LKS, maka kelebihannya diubah jadi uang muka untuk akad ijarah;

d. Jika hasil penjualan < sisa hutang, maka sisa hutang tetap jadi hutang yang wajib dilunasi oleh nasabah dengan cara pelunasan yang disepakati.

2. LKS dan nasabah ex-murabahah dapat membuat akad baru:

a. Ijarah Muntahiyah Bit Tamlik atas barang tersebut mengacu pada fatwa DSN No. 27/DSN-MUI/II/2002 perihal Al-ljarah Al-Muntahiyah bi Al-Tamlik;

b. Mudharabah mengacu pada fatwa DSN No.07/DSN-MUI/IV/2000 perihal pembiayaan Mudharabah (Quradh);

c. Musyarakah mengacu pada fatwa DSN No. 08/DSN-MUI/IV/2000 perihal pembiayaan musyarakah.

\section{METODE PENELITIAN}

Pada penelitian ini, peneliti memakai pendekatan kualitatif dengan jenis penelitian 
Etihad: Journal of Islamic Banking and Finance

Vol. 1, No. 2 Juli-Desember: 132-145

studi kasus. Teknik pengumpulan data dalam penelitian berupa wawancara, observasi, dan dokumentasi. Teknik validitas data yang digunakan adalah trianggulasi teknik, yakni memperoleh data dengan melakukan wawancara, lalu akan diperiksa melalui observasi dan dokumentasi. Selanjutnya analisis data dilakukan dengan reduksi data, penyajian data, dan penarikan kesimpulan.

\section{HASIL DAN PEMBAHASAN}

\section{Nilai Non Performing Financing (NPF) pada Masa Pandemi di Bank BJB Syariah KCP Bogor dan Solusi Penyelesaiannya.}

Non Performing Financing menjadi salah satu indikator mengenai kondisi kesehatan perbankan. Dengan adanya pandemi COVID-19 tentunya memberikan pengaruh kepada kenaikan nilai NPF di Bank BJB Syariah. Selama periode adanya COVID -19, Bapak Susanto sebagai manajer bisnis menyatakan bahwa tidak ada kenaikan nilai NPF yang signifikan. Beliau mengatakan bahwa hanya 1\% dari sebelumnya adanya pandemi COVID -19.

Berdasarkan hasil wawancara informan menyatakan bahwa nilai NPF di masa pandemi tidak mengalami kenaikan yang terlalu signifikan karena sejak awal dapat diatasi dengan melakukan tindakan preventif dengan bersiap-siap melihat pembiayaan untuk direstrukturisasi dari awal. Dengan ada assessment ke nasabah, jika nasabah terdampak COVID langsung disarankan untuk segara mengajukan restrukturisasi.

Pihak bank BJB Syariah melakukan beberapa upaya yang dilakukan oleh pihak bank pun beragam. Mulai dari memberikan restrukturisasi kembali, menjual agunan, take over, bahkan ada juga yang dihapus buku. Proses hapus buku ini dilakukan dengan menghapus neraca Bank BJB Syariah. Pembiayaan demikian tidak tertera pada neraca namun tetap tercatat oleh pihak bank BJB Syariah. Sehingga nasabah masih memiliki kewajiban. Pihak bank akan terus melakukan penagihan kepada nasabah hingga kewajibannya lunas.

\section{Implementasi Restrukturisasi di Bank BJB Syariah KCP Bogor}

Dengan adanya pembiayaan bermasalah bank harus berupaya untuk menanggulanginya, salah satunya dengan memberikan restrukturisasi. Bank BJB Syariah telah melaksanakan kegiatan restrukturisasi sebelum dan setelah adanya pandemi COVID19. Pihak bank akan melihat kemampuan dari nasabah terlebih dahulu. Bapak Rachmat selaku Account Officer menyampaikan bahwa pemberian resrukturisasi harus melewati proses assessment terlebih dahulu. Nasabah akan mengisi form self assessment seperti yang dihimbau oleh OJK dalam POJK perpanjangan masa restrukturisasi. Setelah adanya assessment akan adanya pengelompokan kategori nasabah yang mengajukan restrukturisasi. Ada dua kategori yaitu pembiayaan konsumtif dan juga pembiayaan produktif. Untuk pembiayaan produktif akan dianalisis lebih lanjut berdasarkan penjualan dan pendapatannya, lalu dilihat perbedaan keduanya sebelum dan sesudah adanya COVID-19. Untuk pembiayaan konsumtif bisa mengacu kepada slip gaji dan pendukug lainnya. 
Etihad: Journal of Islamic Banking and Finance

Vol. 1, No. 2 Juli-Desember: 132-145

Bank BJB Syariah KCP Bogor akan melakukan self assessment terlebih dahulu kepada nasabahnya yang mengajukan restrukturisasi. Jika setelah dilakukan assessment dan tidak ditemukan bahwa usaha atau pendapatannya terkena dampak dari COVID-19, maka pihak bank akan memberikan restrukturisasi normal kepada nasabahnya. Hal tersebut berkaitan juga dengan pelaporan kepada OJK, karena jika restrukturisasi tersebut tidak berdampak dari COVID-19 tidak akan diberikan pelabelan khusus. Seperti halnya dalam POJK mengenai perpanjangan restrukturisasi no. 48 pelaporan restrukturisasi yang terdampak COVID harus dilabeli khusus. Pada Bank BJB Syariah khususnya KCP Bogor, tidak ada porsi khusus mengenai pemberian porsi restrukturisasi normal dan juga restrukturisasi atau relaksasi pada masa pandemi. Bank BJB Syariah juga tidak memiliki target mengenai pelaksanaan restrukturisasi yang berbeda dengan tempat lain. Tergantung kepada kondisi nasabah, tidak semua nasabah produktif untuk direstrukturisasi. Kembali kepada segmentasi bisnis nasabah tersebut apabila terdampak COVID-19 maka dapat masuk kedalam kriteria.

Berkas-berkas atau dokumen yang harus disiapkan oleh nasabah dapat dibedakan berdasarkan jenis pembiayaannya. Untuk pembiayaan konsumtif, rata-rata sumber pendapatan tetap atau gaji. Maka dari itu dari pihak bank akan meminta slip gaji terakhir. Dari slip gaji akan dilihat apakah ada pengurangan gaji, karena pada situasi pandemi ini banyak perusahaan yang melakukan pengurangan jam kerja dan berimbas kepada pendapatan nasabah. Selain itu, adanya penyertaan surat dari kantor yang menyatakan bahwa ada pengurangan gaji jika adanya pengurangan. Setelah pengisian form assessment dan pengumpulan slip gaji pihak bank akan melakukan verifikasi data yang selanjutnya akan di analisa. Jika berdasarkan hasil analisa pihak bank disetujui, maka selanjtnya akan adanya adendum akad. Pembiayaan produktif memiliki sedikit perbedaan dengan berkas yang harus dilampirkan. Nasabah diharuskan untuk melampirkan laporan keuangannya baik sebelum dan setelah adanya pandemi. Jika setelah dianalisis nasabah tersebut mengalami penurunan penjualan yang disebabkan oleh COVID-19 maka pembiayaan nasabah tersebut dapat di proses oleh pihak bank.

Dalam menjalankan praktek restrukturisasi Bank BJB Syariah KCP Bogor mengacu kepada Surat Keputusan (SK) yang dikeluarkan oleh Direksi pusat Bank BJB Syariah. Dalam Surat Keputusan tersebut berisikan tentang ketentuan restrukturisasi, reconditioning, dan reschedulling namun tidak di khusus kan pada masa pandemi saja. Di dalamnya di atur mengenai SOP (Standar Operasional Prosedur) yang mengatur restrukturisasi, reconditioning, dan reschedulling. Untuk Surat Keputusan (SK) tidak dapat disebutkan karena berkaitan dengan kerahasiaan bank.

Setelah nasabah mendapatkan restrukturisasi tentunya pihak bank harus tetap memonitoring nasabah dengan rutin. Hal ini juga menjadi salah satu hal yang digaris bawahi dalam POJK. Pihak bank harus terus memantau nasabahnya secara rutin. Memastikan jika nasabah tersebut masih mampu dan masih memiliki kemauan dalam membayarkan kewajibannya. Bank BJB melakukan monitoring kepada nasabahnya setiap bulan, data yang dimiliki oleh Bank BJB Syariah akan selalu dipantau setiap bulannya. Kalau ada 
Etihad: Journal of Islamic Banking and Finance

Vol. 1, No. 2 Juli-Desember: 132-145

keterlambatan maka pihak bank akan segera mengingatkan nasabah untuk membayar angsurannya.

Kendala yang dirasakan oleh pihak Bank BJB Syariah KCP Bogor adalah saat proses verifikasi data. Pihak bank jika dalam kondisi normal akan bertemu nasabah secara langsung karena adanya COVID-19 ruang gerak pihak bank pun terbatas. Karena ada nya WFH, maka membuat nasabah terkadang kesulitan dalam meminta data-data pendukung dari kantor. Selain itu adanya ketidak jujuran dari nasabah juga dapat menjadi kendala dalam pelaksanaan restrukturisasi. Kebanyakan nasabah tidak memberikan data yang benar. Jika diberikan restrukturisasi datanya tidak mendukung, maka sulit untuk bisa direstrukturisasi dan akan menjadi beban bagi bank.

Tidak ada kendala yang dirasakan dari pihak nasabah dalam praktik restrukturisasi ini, tapi ada hal yang nasabah rasa memberatkan, karena adanya penambahan akad, di mana jangka waktunya ditambahkan. Sehingga biaya asuransi ditambahkan selama jangka waktu tambahan. Pihak nasabah harus menyiapkan biaya tambahan untuk membayar asuransi.

\section{Penerapan Restrukturisasi pada Bank BJB Syariah KCP Bogor Berdasarkan POJK No. 48/POJK.03/2020}

Dampak yang dirasakan dengan pemberlakuan POJK terhadap Bank BJB Syariah KCP Bogor adalah bank dapat menahan downgrade. Dengan diperbolehkannya melakukan restrukturisasi atau relaksasi pastinya nasabah akan mampu membayar sesuai dengan jadwal, sehingga status dari kolektabilitas nasabah itu sendiri adalah lancar. Kalau pembiayaan nasabah lancar, maka bank tidak perlu mengeluarkan CKPN (Cadangan Kerugian Penurunan Nilai). Jika bank mengeluarkan CKPN, maka dapat menggerus laba bank tersebut. Dengan adanya relaksasi nilai CKPN pada Bank BJB Syariah masih tetap tidak mengalami kenaikan. Relaksasi dengan CKPN berkaitan, setiap ada pembiayaan baru pasti ada pembentukan CKPN. Namun dengan adanya relaksasi tidak menambah CKPN jika kolektibilitas nasabahnya masih sama.

Selain CKPN, tentunya relaksasi memiliki pengaruh terhadap profit Bank itu sendiri. Dampak yang ditimbulkan dari relaksasi tentunya membuat profit bank menjadi menurun. Karena yang awalnya jadwal angsuran terdiri dari pokok dan bagi hasil atau margin, setelah di restrukturisasi tentunya pihak bank akan membuat jadwal serta pola angsuran yang baru. Jika semakin dirubahnya mengecil, maka otomatis pendapatan atau profit bank akan menurun. Maka dari itu dengan adanya relaksasi atau restrukturisasi sangat memberikan dampak yang signifikan terhadap profit bank itu sendiri.

Dengan adanya relaksasi pembiayaan, tidak merubah akad awal hanya merubah jangka waktu dan besaran pengembalian angsuran. Total nasabah yang mendapatkan relaksasi adalah 3 nasabah dengan segmentasi produktif dengan nilai outstanding 7 Milyar. Ketiga nasabah tersebut setelah melakukan assessment tergolong mendapatkan relaksasi pembiayaan karena usahanya terdampak dari COVID-19. Pada saat pengajuan restrukturisasi COVID-19 disetujui, maka status kolektibilitas nasabah kembali menjadi kategori 1 (lancar). 
Etihad: Journal of Islamic Banking and Finance

Vol. 1, No. 2 Juli-Desember: 132-145

Dengan kembalinya status nasabah menjadi lancar, tentunya akan menguntungkan nasabah karena nama baiknya di BI Checking menjadi lancar kembali.

Dalam penerapan manajemen risiko, Bank BJB Syariah KCP bogor bahkan dari sebelum adanya kebijakan dalam POJK No. 48 mengenai poin manajemen risiko telah melakukan manajemen risiko. Pada Bank BJB Syariah terdapat bagian atau divisi manajemen risiko. Setiap pembiayaan yang bermasalah akan terus dimonitoring. Bahkan untuk action plan, beberapa bulan kedepan berkaitan dengan risiko yang sekiranya akan timbul dalam pembiayaan tersebut. Bank harus selalu melakukan uji ketahanan secara berkala yang berkaitan dengan potensi kualitas pembiayaan yang direstrukturisasi. Jika nasabah terdapat kemacetan dalam pembayaran, maka harus segera mencari solusi. Misalnya dengan jual agunan atau jual bersama ataupun lelang. Manajemen risiko bukan bagian yang terpisahkan dari restrukturisasi.

\section{Penerapan Restruktusasi Berdasarkan Fatwa DSN MUI}

Dalam pelaksanaan restrukturisasi Bank harus mengacu fatwa yang dikeluarkan oleh Dewan Syariah Nasional. Fatwa tersebut adalah:

1. Tentang penyelesaian piutang murabahah bagi nasabah yang tidak mampu bayar, Fatwa DSN No. 47/DSN-MUI/II/2005.

Dalam penerapannya Bank BJB Syariah KCP Bogor akan melakukan penawaran restrukturisasi terlebih dahulu. Setelah pemberian restrukturisasi nasabah masih mengalami keberatan, nasabah disarankan untuk menjual objek murabahah atau jaminan nya, nasabah bisa menjual dengan sendiri atau bisa juga dengan melalui LKS. Nasabah diwajibkan melunasi hutangnya dari hasil penjualan objek tersebut. Jika setelah dijual masih terdapat kekurangan atas sisa hutangnya, maka nasabah tetap diwajibkan untuk membayar sisa hutangnya. Rata-rata hasil penjualan dari objek tersebut masih memiliki kekurangan dari sisa hutang yang dimiliki.

2. Fatwa DSN No. 48/DSN-MUI/II/2005 perihal penjadwalan kembali tagihan murabahah.

Berdasarkan hasil penelitian pada Bank BJB Syariah KCP Bogor, tidak ada penambahan dalam sisa tagihan yang ada. Hanya ada penambahan biaya asuransi dengan bertambahnya jangka waktu nasabah. Perpanjangan masa pembayaran juga didasarkan atas kesepakatan kedua belah pihak. Pembebanan biaya hanya boleh dilakukan kepada biaya rill atau biaya langsung yang secara jelas dikeluarkan akibat wanprestasi suatu akad. Berdasarkan Fatwa DSN MUI tentang $t a^{\prime} d w i d h$, LKS dan nasabah diperbolehkan menyepakati apabila nasabah terlambat membayar dan mengakibatkan kerugian rill kepada LKS, maka LKS berhak meminta ganti rugi atas biaya biaya yang ditimbulkan dari keterlambatan nasabah membayar kewajibannya.

3. Fatwa DSN No.49/DSN-MUI/II/2005 perihal konversi akad murabahah.Perihal konversi akad murabahah.

Dalam pelaksanaan restrukturisasi, bank BJB Syariah mengacu pada fatwa-fatwa DSN MUI. Karena setiap kegiatan di Bank BJB Syariah diawasi oleh DPS. Tidak hanya 
Etihad: Journal of Islamic Banking and Finance

Vol. 1, No. 2 Juli-Desember: 132-145

restrukturisasi tetapi seluruh produk yang dimiliki bank BJB Syariah juga berpaku kepada Fatwa DSN MUI.

\section{KESIMPULAN}

Hasil penelitian menunjukkan bahwa praktik restrukturisasi pembiayaan murabahah di Bank BJB Syariah KCP Bogor dijalankan sebagai upaya penyelamatan pembiayaan yang bermasalah. Restrukturisasi dilakukan sebelum dan sesudah pandemi. Dengan berpegang POJK serta SK yang diterbitkan oleh Direksi, Bank BJB Syariah KCP Bogor memiliki pedoman dalam pemberian restrukturisasi. Selain itu, adanya monitoring yang dijalankan oleh pihak Bank BJB Syariah guna menghindari adanya pembiayaan yang bermasalah kembali. Pelaksanaan restrukturisasi jika ditinjau dari POJK, khususnya POJK 48 menunjukkan beberapa poin penting yang harus diperhatikan oleh perbankan. Bank BJB Syariah KCP Bogor, memiliki pedoman untuk menetapkan debitur yang terdampak COVID-19, melakukan penilaian terhadap debitur, membentuk cadangan untuk debitur yang dinilai tidak mampu, mempertimbangkan ketahanan modal, dan menguji ketahanan secara berkala. Selain itu pelaksanaan restrukturisasi memperhatikan fatwa DSN MUI No 47,48,49. Dalam penerapannya Bank BJB Syariah KCP Bogor, akan melakukan penawaran restrukturisasi terlebih dahulu. Setelah pemberian restrukturisasi, jika nasabah masih mengalami keberatan, maka nasabah disarankan untuk menjual objek murabahah atau jaminan nya, nasabah bisa menjual dengan sendiri atau bisa juga dengan melalui LKS. Nasabah diwajibkan melunasi hutangnya dari hasil penjualan objek tersebut, tidak ada biaya tambahan akad dalam perpanjangan jangka waktu.

\section{REFERENSI}

Albanjari, F. R., \& Kurniawan, C. (2020). Jurnal Eksyar (Jurnal Ekonomi Syariah ) Jurnal Eksyar ( Jurnal Ekonomi Syariah ). 07(01), 24-36.

Bank Indonesia. (2011). Peraturan Bank Indonesia. Www.Bi.Go.Id. https://www.bi.go.id/id/E404.aspx?RequestedUrl=https://www.bi.go.id:443/id/peratu ran/perbankan/Pages/pbi_130911.aspx (28

covid19.id. (n.d.). No Titl. Www.Covid19.Go.Id. Retrieved November 20, 2020, from https://www.covid19.go.id/

Djami, F. (2012). Penyelesaian Pembiayaan Bermasalah di Bank Syariah. Sinar Grafika.

DSN-MUI. (2017). Fatwa Dewan Syariah Nasional No. 111/DSN-MUI/IX/2017 tentang Akad Jual Beli Murabahah. 19. https://dsnmui.or.id/akad-jual-beli-murabahah/

DSN MUI. (2005). Fatwa DSN MUI Tentang Penjadwalan Kembali Tagihan Murabahah. 48.

Hariyanto, A., Asra, M., \& Al-Hanun, W. (2018). Restrukturisasi Pembiayaan Murabahah Analisis Yuridis Peraturan Bank Indonesia. Lisan Al-Hal, 12(2), 329-346. https://journal.ibrahimy.ac.id/index.php/lisanalhal/article/view/158 
Etihad: Journal of Islamic Banking and Finance

Vol. 1, No. 2 Juli-Desember: 132-145

Hasbi, S., \& Hadi, K. (2016). Evaluasi Pembiayaan Perumahan Akad Murabahah Versus Kredit Konvensional Berdasarkan Volatilitas Harga. Jurnal Akuntansi Dan Investasi, 17(1), 2241. https://doi.org/10.18196/jai.2016.0042.22-41

Ismail. (2013). Manajemen Perbankan Dari Teori Menuju Aplikasi. Kencana.

Maulana, S. J., \& Hendri. (2016). Prosedur Proses Klaim Jamkrindo Terhadap Kredit Kupedes Rakyat Studi Kasus PT. Bank Rakyat Indonesia (PERSERO) Tbk. 4, 65-79.

OJK. (2020a). 11/Pojk.03. 2019, 1-16.

OJK. (2020b). Peraturan POJK Nomor 48/POJK.03/2020.

OJK. (2020c). Snapshot Perbankan Syariah Indonesia 2020.

Ubaidillah, M., \& Syah Aji, R. H. (2020). Tinjauan Atas Implementasi Perpanjangan Masa Angsuran Untuk Pembiayaan Di Bank Syariah Pada Situasi Pandemi Covid-19. Islamic Banking: Jurnal Pemikiran Dan Pengembangan Perbankan Syariah, 6(1), 1-16. https://doi.org/10.36908/isbank.v6i1.159

Umam, K. (2016). Perbankan Syariah Dasar-Dasar Dan Dinamika Perkembangannya Di Indonesia. PT RajaGrafindo Persada.

Wahyudi, C. A., \& Arbay, E. A. (2011). The Impact of OJK Regulation No. 48/POJK.03/2020 on the Quality of Credit and Risk Management of Banking Credit Christanto. Journal of Economics and Business, 16(110), 853-862. https://doi.org/10.31014/aior.1992.04.01.332

Wiroso. (2007). Produk perbankan syariah. 